\title{
Emerging Issues in Rangeland Ecohydrology: Vegetation Change and the Water Cycle
}

\author{
Bradford P. Wilcox ${ }^{1}$ and Thomas L. Thurow ${ }^{2}$ \\ Authors are ${ }^{1}$ Professor, Rangeland Ecology and Management Department, Texas A\&M University, \\ College Station, TX 77843-2126; and ${ }^{2}$ Professor, Renewable Resources Department, \\ University of Wyoming, Laramie, WY 82071-3354.
}

\begin{abstract}
Rangelands have undergone-and continue to undergo-rapid change in response to changing land use and climate. A research priority in the emerging science of ecohydrology is an improved understanding of the implications of vegetation change for the water cycle. This paper describes some of the interactions between vegetation and water on rangelands and poses 3 questions that represent high-priority, emerging issues: 1) How do changes in woody plants affect water yield? 2) What are the ecohydrological consequences of invasion by exotic plants? 3) What ecohydrological feedbacks play a role in rangeland degradation processes? To effectively address these questions, we must expand our knowledge of hydrological connectivity and how it changes with scale, accurately identify "hydrologically sensitive" areas on the landscape, carry out detailed studies to learn where plants are accessing water, and investigate feedback loops between vegetation and the water cycle.
\end{abstract}

Key Words: water yield, range ecology, range hydrology, runoff, aquifer recharge, desertification, semiarid, degradation, invasive species

\section{INTRODUCTION}

Many rangelands are changing in dramatic ways. Several trends of change in the composition and structure of vegetation communities have been documented in many different regions of the globe. These include 1) replacement of grasslands and savannas with woodlands (Scholes and Archer 1997; Van Auken 2000); 2) increased prevalence of exotic, invasive species (Sheley and Petroff 1999); 3) conversion of rangeland to tame pasture or cultivated crops, e.g., eucalyptus shrublands in Australia (Walker et al. 1993) and Cerrado in Brazil (Cardille and Foley 2003); and 4) degradation of rangelands because of unsustainable fuel-wood harvest and heavy grazing (Dregne 2002). These types of changes in the structure and composition of vegetation communities are often associated with significant, but not well understood, disturbances in hydrologic and related biogeochemical processes (Archer et al. 2001).

Ecobydrology, a cross-disciplinary science that melds ecology with hydrology, focuses on the interactions between the water cycle and the distribution, structure, function, and dynamics of biological communities (Nuttle 2002; Hannah et al. 2004). Although ecohydrology has roots in many disciplines, including rangeland hydrology (Bonell 2002), as an emerging field it still lacks a strong theoretical foundation with respect to soilvegetation-climate interactions (Kerkhoff et al. 2004). We are confident that as the field matures this weakness will be addressed. Rangeland hydrology, on the other hand, has a well-

This work was partially supported by National Science Foundation Grant 0233667 , Collaborative Research: WCR: Ecohydrology of Semiarid Woodlands: Role of Woody Plants in the Water Cycle.

Correspondence: Bradford P. Wilcox, Rangeland Ecology and Management Department, Texas A\&M University, College Station, TX 77843-2126. Email: bwilcox@tamu.edu

Manuscript received 11 May 2005; manuscript accepted 16 October 2005. established lineage of applied research regarding how management techniques (such as grazing, fire, and mechanical and chemical treatments) alter soil structure and the extent and composition of vegetation cover, which in turn affects hydrologic and erosion processes (Branson et al. 1981; Thurow 1991).

As demand for water increasingly outstrips supply in many semiarid regions of the world, there is intensifying pressure, from both the scientific and policy communities, to understand how the water cycle is influenced by changes in the structure and function of vegetation and vice versa. To gain this understanding, researchers must consider hydrologic effects that are manifested in different ways at different scales of observation (National Research Council 1999). Research into the interconnections between the water cycle and vegetation at the watershed scale is aided by new technologies in the areas of image analysis and modeling, as well as by enhanced computer computational capacity, thus setting the stage for analysis of water stores and fluxes on rangelands at expanded scales of inquiry.

In this paper we highlight 3 emerging issues that we believe will dominate rangeland ecohydrology research in the coming decade. Each relates to how changes in vegetation affect the hydrology of a region and vice versa. Our discussion is not exhaustive, but rather illustrative of the ecohydrological research challenges that lie ahead. A complementary and more comprehensive discussion of these and other issues is provided in Newman et al. (2006).

\section{EMERGING ISSUES FOR ECOHYDROLOGY RESEARCH IN RANGELANDS}

\section{How do Changes in Woody Plants Affect Water Yield?}

The linkage between vegetation type and water yield (runoff and deep drainage beyond root access) has long been a subject of debate. Many speculate that evapotranspiration (ET) rates in 
woodlands are greater than in grasslands because trees tend to lose more water via interception (water adheres to foliage and is evaporated back to the atmosphere without reaching the soil) (Thurow et al. 1987) and transpiration (trees have more extensive leaf areas and root systems than do typical rangeland herbaceous communities) (Ansley et al. 1991; Schenk and Jackson 2005). Therefore, the oft-heard argument is that if ET loss can be reduced by managing rangelands for a greater grass component and a lesser tree and shrub component, more water will be available for runoff and/or deep drainage.

This argument has been proved true in a variety of humid, montane, and Mediterranean climates, where studies have shown increases in water yields tied to removal of trees and shrubs (Bosch and Hewlett 1982; Zhang et al. 2001). Indeed, there are dramatic examples of unintended hydrologic consequences associated with a change in woody vegetation cover. For example, large-scale conversion of eucalyptus shrublands to cultivated farmlands in southern Australia led to a rise in groundwater tables (with increased soil salinity as an unfortunate byproduct) (Allison et al. 1990; Walker et al. 2002). Conversely, Jobbagy and Jackson (2004) documented a decline in groundwater recharge in the humid Argentine Pampas following afforestation.

In semiarid rangelands, however, the feasibility of using tree and shrub removal as a means of increasing water yield has not yet been demonstrated on scales that are meaningful in terms of regional water supply (Wilcox 2002). In the 1960s and 1970s, the potential for such a strategy was extensively investigated in the southwestern United States; anecdotal observations and estimates of ET savings associated with shifts in cover type from trees/shrubs to grasses led to the conclusion that there was significant potential for an increase in localized water yield (summarized by Hibbert 1983). In addition, modeling studies have indicated that the effects of shrub encroachment on water yield may be important on rangelands where drainage is rapid and deep (Wu et al. 2001; Afinowicz et al. 2005).

Even though many studies have made a theoretical case for increasing water yields on rangelands through shrub control, field studies undertaken to empirically validate such claims have shown that changes in the water budget tend to be sitespecific, tenuous, and difficult to measure accurately (Huxman et al. 2005). One problem is that the anticipated reductions in ET from tree and shrub removal can be offset by increases in transpiration from the herbaceous plants and by evaporation from newly exposed soil.

Those studies that have documented genuine increases in water yield have been done at sites with the following characteristics: 1) precipitation is out of phase with evapotranspiration (i.e., winter precipitation regimes) and 2) physical characteristics facilitate rapid subsurface movement of water from the site (allowing the water to avoid being lost through ET and to instead become deep drainage or runoff). Such rapid transport of water usually requires shallow soils having properties that hasten infiltration and percolation and that overlie either a fractured geologic substrate (contributing to deep drainage) or an impervious layer (facilitating delivery of interflow to a seep, spring, or base flow of a stream).

Most semiarid rangelands do not have the combination of climatic, soil, and geologic characteristics that allow for reliable, substantial water yield. Nevertheless, if shrub control is targeted to those sites that do have the traits required for high water yield potential, the dividends could be substantial. They may range from providing better water supply for a ranch to augmenting the amount of water available to downstream municipalities.

Recent work highlights the importance of vegetation cover in regulating groundwater recharge in semiarid settings. For example, in many arid and semiarid settings populated by relatively deep-rooted shrubs, there has been no deep drainage, and hence no recharge, in the last 10,000 years (Walvoord et al. 2002; Walvoord and Phillips 2004; Seyfried et al. 2005). Similarly_but on a more immediate time scale-research is documenting that the presence or absence of vegetation controls recharge rates even in very dry settings (Gee et al. 1994; Scanlon et al. 2005; Scanlon et al. 2006). This finding has particular importance for the issue of contaminant transport.

Ecohydrology is in its infancy as far as understanding how or whether the potential for increasing water yield at one scale of resolution is manifested at another scale. Most of the experimental work related to this question has been done at the tree or stand scale, whereas the scale of greatest interest is the much larger landscape scale, for which our understanding of vegetation-water interactions is especially weak. Consequently, in the coming decades research into the ecohydrologic implications of changing woody plant cover will realize the greatest benefits by focusing on 1) improving our understanding of pathways and processes of streamflow generation; 2) accurately identifying "hydrologically sensitive" areas on the landscape-those likely to have the potential for significant increases in water yield from shrub control; and 3) conducting more research, aided by stableisotope technologies, to understand where the woody plants are accessing water throughout the soil profile and how this water is hydrologically connected to the rest of the landscape.

\section{What are the Ecohydrological Consequences of Invasion by Exotic Plants?}

Invasion by nonnative species has completely transformed the nature and character of many rangelands, the hydrologic implications of which are not fully understood. Two of the numerous examples are 1) the conversion of native grasslands and shrublands to grasslands dominated by exotic grasses and 2) the colonization of riparian landscapes by saltcedar (Tamarix spp.) and Russian olive (Elaeagnus angustifolia L.).

A well-known example of replacement of native by annual grasslands took place in California more than 100 years ago. Other examples include the conversion of sagebrush shrublands in the northwestern United States to stands of almost exclusively cheatgrass (Bromus tectorum L.) (Norton et al. 2004); and the replacement of native by annual grasses in the savannas of Australia (Ash et al. 1994). In the 2 latter cases, the conversion is reinforced and maintained by frequent fires.

For upland rangelands, several studies have examined the implications of such conversions for nutrient cycling (Evans et al. 2001; Blank and Young 2004; Norton et al. 2004), and considerable research has been done on the effects of exotic plant species on native vegetation (Sheley and Petroff 1999). In addition, recent work has examined the relationship between exotic grasses and rainfall pulses (Huxman et al. 2004; Clarke et al. 2005). But very little work has directly examined how 
invasive species might be influencing the water cycle in these environments.

In contrast, for riparian systems the water-use characteristics of invasive exotic species have been extensively studied at the individual tree or stand scale, particularly those of exotic phreatophytes such as saltcedar and Russian olive (Glenn and Nagler 2005). But the findings of these studies have not been extensively tested at larger scales of resolution. Furthermore, in many river systems of the western United States, the "scouring" effect of annual flooding historically prevented overgrowth of woody plants in riparian corridors; however, in recent times the construction of dams and consequent moderation of flow may have changed these environments such that establishment of phreatophytic trees and shrubs, native or exotic, may be inevitable as long as these unnatural flow regimes are maintained (Levine and Stromberg 2001; Lite and Stromberg 2005).

There is a growing consensus that if invasive phreatophytes are replaced by other woody plants, water savings will be small at best (Glenn and Nagler 2005), but if they are replaced with herbaceous plants, water savings could be as high as $500 \mathrm{~mm} / \mathrm{yr}$ (Wilcox et al. 2005). However, some important information gaps regarding the impacts of invasive species on riparian ecohydrology remain: 1) the amounts of water used by exotic plants vs. native plants at larger, management-relevant scales (stream segment to basin), and 2) the feasibility of riparian restoration in systems where the flow regime has been fundamentally altered by dams or other engineering works.

\section{What Ecohydrological Feedbacks Play a Role in Rangeland Degradation Processes?}

Degradation, or desertification, is taking place on a significant portion of the world's rangelands (Middleton and Thomas 1997; Dregne 2002) and is perhaps the most important environmental problem on rangelands worldwide. The linkage between degradation and the decline in freshwater resources is as real as it is complicated (Reynolds and Stafford Smith 2002; Duda 2003; Ripl 2003).

Whether resulting from loss of topsoil or physical and chemical deterioration, rangeland degradation is often preceded by a reduction in vegetation cover and/or biological soil crust (Belnap 1995; Dregne 2002). Overgrazing (Kerley and Whitford 2000; Manzano et al. 2000), deforestation and use of woody plants for fuel (Abahussain et al. 2002; Asner et al. 2004), and climatic variation (Le Houerou 1996) all potentially drive the degradation process. In addition, feedbacks between climate and anthropogenic factors (Puigdefabregas and Mendizabal 1998; Reynolds and Stafford Smith 2002) complicate these relationships.

Ludwig et al. (1997) suggested that dryland degradation is created and perpetuated by the acceleration of forces that cause water, soil, and nutrients to be lost or "leaked" from the system. Sometimes the first manifestation of this process is a reapportionment of water (Cornet et al. 1992; Bhark and Small 2003) and nutrients (Schlesinger et al. 1990) on the landscape: resources are carried out of canopy interspaces, leaving those zones degraded, and are concentrated under shrub canopies (Ludwig et al. 1999). These ideas have been experimentally verified at a few locations (Shachak et al. 1998; Wilcox et al. 2003; Ludwig et al. 2005). Other research indicates that if those shrub canopies are reduced or eliminated, less and less water is retained on the landscape, accelerating the degradation process (Wu et al. 2000; Ludwig et al. 2005).

Most ecohydrology studies of desertification feedback loops have been conducted at a plot or field scale, affording little insight as to how these feedbacks are manifested at the basin or landscape scale. Anecdotal evidence from arid regions of India suggests that the extension and widening of stream channels may be because of higher and more frequent runoff in the wake of desertification (Sharma 1998). Puigdefabregas and Mendizabal (1998) theorize, on the basis of work in Mediterranean areas of Spain, that some degradation of rangelands is actually required to maintain streamflow. They observe that when these rangelands recover, there are significant reductions in surface runoff.

In the coming decades, ecohydrology research must address the feedback loops between vegetation, soil degradation, and water at various scales. Insights into how such feedbacks are initiated, perpetuated, and manifested at different scales is currently the weak link in our ability to devise sustainable restoration strategies (Tongway and Ludwig 1996; Manu et al. 1999). The ultimate challenge will be linking an ecohydrological understanding with the socioeconomic drivers of degradation (Reynolds 2001). The Dahlem Desertification Paradigm is one effort to do just that (Reynolds and Stafford Smith 2002).

\section{SUMMARY}

The issues we have identified are obviously not exhaustive, but they are some of the key emerging issues related to water on rangelands. Ecohydrology is a science that is well positioned to help rangeland managers develop the insights needed to attain primary rangeland management objectives, namely, optimization of water yields and restoration of degraded areas. The many gaps that remain in the current state of our knowledge limit our ability to predict how the water cycle is influenced by 1) changes in the structure and composition of native vegetation communities and 2) changes associated with the invasion and establishment of exotic species. These gaps also hinder our ability to understand how overconsumption of vegetation can alter hydrologic dynamics, which is important for preventing degradation and devising restoration strategies. We anticipate that with the application of new and more advanced technologies, coupled with an improved understanding of soil-vegetation-water interactions, rapid advances can be made in addressing the priority research needs identified in this paper.

\section{ACKNOWLEDGMENTS}

Many of the ideas expressed here are a direct outcome of a special session at the 2005 Annual Meeting of the Society for Range Management, Emerging Issues in Rangeland Ecohydrology. We are grateful to colleagues who participated in this session, as well as to others who generously shared their ideas related to rangeland ecohydrology.

\section{LITERATURE CITED}

Abahussain, A. A., A. S. Abdu, W. K. Al-Zubari, N. A. El-Deen, and M. Abdul-Raheem. 2002. Desertification in the Arab Region: analysis of current status and trends. Journal of Arid Environments 51:521-545. 
Afinowicz, J. D., C. L. Munster, and B. P. Wilcox. 2005. Modeling the effects of brush management for increasing water yield on the Edwards Plateau, Texas. Journal of the American Water Resources Association 41:181-193.

Allison, G. B., P. G. Cook, S. R. Barnett, G. R. Walker, I. D. Jolly, and M. W. HuGHES. 1990. Land clearance and river salinization in the western Murray Basin, Australia. Journal of Hydrology 119:1-20.

Ansley, R. J., P. W. JaCOBY, AND R. Hicks. 1991. Leaf and whole plant transpiration in honey mesquite following severing of lateral roots. Journal of Range Management 44:577-583.

Archer, S., T. W. Boutton, and K. A. HibBard. 2001. Trees in grasslands: biogeochemical consequences of woody plant expansion. In: E.-D. Schulze, M. Heimann, S. Harrison, E. Holland, J. Lloyd, I. Prentice, and D. Schimel [EDS.]. Global Biogeochemical Cycles in the Climate System. Durham, NC: Academic Press. p 115-138.

Ash, A. J., J. A. Bellamy, and T. G. H. Stockwell. 1994. State and transition models for rangelands. 4. Application of state and transition models to rangelands in Northern Australia. Tropical Grasslands 28:223-228.

Asner, G. P., A. J. Elmore, L. P. Olander, R. E. Martin, and A. T. Harris. 2004. Grazing systems, ecosystem responses, and global change. Annual Review of Environment and Resources 29:261-299.

BELNAP, J. 1995. Surface disturbances: their role in accelerating desertification. Environmental Monitoring and Assessment 37:39-57.

Bhark, E., And E. Small. 2003. The relationship between plant canopies and the spatial variability of infiltration in grasslands and shrublands of the northern Chihuahuan desert, N.M. Ecosystems 6:185-196.

Blank, R. R., and J. A. Young. 2004. Influence of three weed species on soil nutrient dynamics. Soil Science 169:385-397.

BoneLL, M. 2002. Ecohydrology-a completely new idea? Hydrological Sciences Journal 47:809-810.

Bosch, J. H., and J. D. Hewlett. 1982. A review of catchment experiments to determine the effect of vegetation changes on water yield and evapotranspiration. Journal of Hydrology 55:3-23.

Branson, F. A., G. G. Gifford, K. G. Renard, and R. F. Hadley. 1981. Rangeland hydrology. Dubuque, IA: Kendall/Hunt Publishing. $84 \mathrm{p}$.

Cardille, J. A., and J. A. Foley. 2003. Agricultural land-use change in Brazilian Amazonia between 1980 and 1995: evidence from integrated satellite and census data. Remote Sensing of Environment 87:551-562.

Clatke, P. J., P. K. Latz, and D. E. Albrecht. 2005. Long-term changes in semi-arid vegetation: invasion of an exotic perennial grass has larger effects than rainfall variability. Journal of Vegetation Science 16:237-248.

Cornet, A., C. Montana, J. P. Delhoume, and J. Lopez-Portillo. 1992. Water flows and the dynamics of desert vegetation stripes. In: A. J. Hansen and F. Di Castri [EDS.]. Landscape boundaries: Consequences for biotic diversity and ecological flows. New York, NY: Springer-Verlag. p 327-345.

Dregne, H. E. 2002. Land degradation in the drylands. Arid Land Research and Management 16:99-132.

DuDA, A. M. 2003. Integrated management of land and water resources based on a collective approach to fragmented international conventions. Philosophical Transactions of the Royal Society of London, Series B-Biological Sciences 358:2051-2062.

Evans, R. D., R. Rimer, L. Sperry, and J. Belnap. 2001. Exotic plant invasion alters nitrogen dynamics in an arid grassland. Ecological Applications 11:1301-1310.

Gee, G. W., P. J. Wierenga, B. J. Andraski, M. H. Young, M. J. Fayer, and M. L. RockHoLD. 1994. Variations in water balance and recharge potential at three western desert sites. Soil Science Society of America Journal 58:63-72.

Glenn, E. P., And P. L. Nagler. 2005. Comparative ecophysiology of Tamarix ramosissima and native trees in western U.S. riparian zones. Journal of Arid Environments 61:419-446.

Hannah, D. M., P. J. Wood, and J. P. Sadler. 2004. Ecohydrology and hydroecology: a new paradigm? Hydrological Processes 18:3439-3445.

HiBBERT, A. R. 1983. Water yield improvement potential by vegetation management on western rangelands. Water Resources Bulletin 19:375-381.

Huxman, T. E., J. M. Cable, D. D. Ignace, J. A. Ellts, N. B. English, J. Weltzin, and D. G. Williams. 2004. Response of net ecosystem gas exchange to a simulated precipitation pulse in a semi-arid grassland: the role of native versus nonnative grasses and soil texture. Oecologia 141:295-305.

Huxman, T. E., B. P. Wilcox, D. D. Breshears, R. L. Scott, K. A. Snyder, E. E. Small, K. Hultine, W. T. Pockman, and R. B. Jackson. 2005. Ecohydrological implications of woody plant encroachment. Ecology 86:308-319.

JobBaGy, E. G., AND R. B. JaCKSON. 2004. Groundwater use and salinization with grassland afforestation. Global Change Biology 10:1299-1312.

Kerkhoff, A. J., S. N. Martens, and B. T. Milne. 2004. An ecological evaluation of Eagleson's optimality hypotheses. Functional Ecology 18:404-413.

Kerley, G. I. H., AND W. G. Whitford. 2000. Impact of grazing and desertification in the Chihuahuan Desert plant communities, granivores and granivory. American Midland Naturalist 144:78-91.

Le Houerou, H. N. 1996. Climate change, drought and desertification. Journal of Arid Environments 34:133-185.

LeVIne, C. M., AND J. C. Stromberg. 2001. Effects of flooding on native and exotic plant seedlings: implications for restoring south-western riparian forests by manipulating water and sediment flows. Journal of Arid Environments 49:111-131.

Lite, S. J., AND J. C. Stromberg. 2005. Surface water and ground-water thresholds for maintaining Populus-Salix forests, San Pedro River, Arizona. Biological Conservation 125:153-167.

Ludwig, J. A., D. J. Tongway, D. Freudenberger, J. Noble, and K. Hodgkinson. 1997. Landscape ecology function and management: Principles from Australia's rangelands. Collingwood, Australia: CSIRO Publications. $158 \mathrm{p}$.

LudWIG, J. A., D. J. Tongway, AND S. G. MARSDEN. 1999. Stripes, strands or stipples: modelling the influence of three landscape banding patterns on resource capture and productivity in semi-arid woodlands, Australia. Catena 37:257-273.

Ludwig, J. A., B. P. Wilcox, D. D. Breshears, D. J. Tongway, and A. C. Imeson. 2005. Vegetation patches and runoff-erosion as interacting ecohydrological processes in semiarid landscapes. Ecology 86:288-297.

Manu, A., T. L. Thurow, A. S. R. Juo, and I. Zanguina. 1999. Agroecological impacts of five years of a practical program for restoration of a degraded Sahelian watershed. In: R. Lal [ED.]. Integrated watershed management in the global ecosystem. Boca Raton, FL: CRC Press. p 145-163.

Manzano, M. G., J. Navar, M. Pando-Moreno, and A. Martinez. 2000. Overgrazing and desertification in northern Mexico: highlights on northeastern region. Annals of Arid Zone 39(3):285-304.

Middleton, N. J., And D. S. G. Thomas. 1997. World atlas of desertification. London, UK: Edward Arnold. $182 \mathrm{p}$.

National Research Council. 1999. Hydrologic science priorities for the U.S. Global Change Research Program. Washington, DC: National Academy Press. 34 p.

Newman, B. D., B. P. Wilcox, S. Archer, D. D. Breshears, C. N. Dahm, C. J. Duffy, N. G. McDowell, F. M. Phillips, B. R. Scanlon, and E. R. Vivoni. 2006. The ecohydrology of arid and semiarid environments: a scientific vision. Water Resources Research (in press).

Norton, J. B., T. A. Monaco, J. M. Norton, D. A. Johnson, and T. A. Jones. 2004. Soil morphology and organic matter dynamics under cheatgrass and sagebrushsteppe plant communities. Journal of Arid Environments 57:445-466.

NuttLE, W. K. 2002. Eco-hydrology's past and future in focus. EOS 83:205, $211-212$.

Puigdefabregas, J., and T. Mendizabal. 1998. Perspectives on desertificationwestern Mediterranean. Journal of Arid Environments 39:209-224.

Reynolds, J. F. 2001. Desertification. In: S. Levin [Ed.], Encyclopedia of biodiversity. Volume 2. San Diego, CA: Academic Press. p 61-78.

ReYnolds, J. F., AND D. M. StafFord Smith. 2002. Introduction-do humans cause deserts? In: J. F. Reynolds and D. M. Stafford Smith [EDS.]. Do humans cause deserts? Berlin, Germany: Dahlem University Press. p 1-23.

RIPL, W. 2003. Water: the bloodstream of the biosphere. Philosophical Transactions of the Royal Society of London, Series B-Biological Sciences 358:1921-1934.

Scanlon, B. R., D. G. Levitt, R. C. Reedy, K. E. Keese, and M. J. Sully. 2005. Ecological controls on water-cycle response to climate variability in deserts. Proceedings of the National Academy of Sciences of the United States of America 102:6033-6038.

Scanlon, B. R., R. C. Reedy, D. A. Stonestrom, D. E. Prudic, and K. F. Dennehy. 2006. Impact of land use and land cover change on groundwater recharge and quality in the southwestern US. Global Change Biology 11(10):1577-1593. 
Schenk, H. J., AND R. B. Jackson. 2005. Mapping the global distribution of deep roots in relation to climate and soil characteristics. Geoderma 126:129-140.

Schlesinger, W. H., J. F. Reynolds, G. L. Cunningham, L. F. Huenneke, W. M. Jarrell, R. A. Virginia, AND W. G. Whitford. 1990. Biological feedbacks in global desertification. Science 247:1043-1048.

Scholes, R. J., And S. R. ARcher. 1997. Tree-grass interactions in savannas. Annual Review of Ecological Systems 28:517-544.

Seyfried, M. S., S. Schwinning, M. A. Walvoord, W. T. Pockman, B. D. Newman, R. B. JaCKSON, AND F. M. PhilLIPS. 2005. Ecohydrological control of deep drainage in semiarid regions. Ecology 86(2):277-287.

SHACHAK, M., M. SaCHS, and I. Moshe. 1998. Ecosystem management of desertified shrublands in Israel. Ecosystems 1:475-483.

Sharma, K. D. 1998. The hydrological indicators of desertification. Journal of Arid Environments 39:121-132.

Sheley, R. J., and J. K. Petroff. 1999. Biology and management of noxious rangeland weeds. Corvallis, Oregon: Oregon State University Press. 438 p.

ThuRow, T. L. 1991. Hydrology and erosion. In: R. K. Heitschmidt and J. W. Stuth [EDS.]. Grazing management: an ecological perspective. Portland, OR: Timber Press. p 141-159.

Thurow, T. L., W. H. Blackburn, S. D. Warren, and C. A. Taylor, JR. 1987. Rainfall interception by midgrass, shortgrass, and live oak mottes. Journal of Range Management 40:455-460.

Tongway, D. J., And J. A. Ludwig. 1996. Rehabilitation of semiarid landscapes in Australia. 1. Restoring productive soil patches. Restoration Ecology 4:388-397.

Van Auken, 0. W. 2000. Shrub invasions of North American semiarid grasslands. Annual Review of Ecology and Systematics 31:197-215.

Walker, G. R., L. Zhang, T. W. Ellis, T. J. Hatton, and C. Petheram. 2002. Estimating impacts of changed land use on recharge: review of modelling and other approaches appropriate for management of dryland salinity. Hydrogeology Journal 10:68-90.

Walker, J., F. Bullen, and B. G. Williams. 1993. Ecohydrological changes in the Murray-Darling Basin. I. The number of trees cleared over two centuries. Journal of Applied Ecology 30:265-273.

Walvoord, M. A., AND F. M. Phillips. 2004. Identifying areas of basin-floor recharge in the Trans-Pecos region and the link to vegetation. Journal of Hydrology 292:59-74.

Walvoord, M. A., M. A. Plummer, F. M. Phillips, and A. V. Wolfsberg. 2002. Deep arid system hydrodynamics. 1. Equilibrium states and response times in thick desert vadose zones. Water Resources Research 38:44-1-44-15.

WiLcox, B. P. 2002. Shrub control on rangelands: a process-based viewpoint. Journal of Range Management 55:318-326.

Wilcox, B. P., D. D. Breshears, and C. D. Allen. 2003. Ecohydrology of a resourceconserving semiarid woodland: effects of scale and disturbance. Ecological Monographs 73:223-239.

Wilcox, B. P., W. A. Dugas, M. K. Owens, D. N. Ueckert, and C. R. Hart. 2005. Shrub control and water yield on Texas rangelands: Current state of knowledge. College Station, TX: Texas Agricultural Experiment Station. Research Report 05-1. 20 p.

Wu, X. B., E. J. Redeker, and T. L. Thurow. 2001. Vegetation and water yield dynamics in an Edwards Plateau watershed. Journal of Range Management 54:98-106.

Wu, X. B., T. L. Thurow, and S. G. Whisenant. 2000. Fragmentation and changes in hydrologic function of tiger bush landscapes, south-west Niger. Journal of Ecology 88:790-800.

Zhang, L., W. R. Dawes, and G. R. Walker. 2001. Response of mean annual evapotranspiration to vegetation changes at the catchment scale. Water Resources Research 37:701-708. 